\title{
Diverse trajectories of industrial restructuring and labour organising in India
}

Satoshi Miyamura

Department of Economics, SOAS, University of London, UK

Thornhaugh Street, Russell Square, London WC1H 0XG. Tel: +44 (0) 2078984544.

Email: sm97@ soas.ac.uk

\begin{abstract}
It is often claimed that industrial restructuring leads to diminished roles for trade unionism and other forms of labour organisations by informalising employment and relocating production. Drawing on selected case studies from long term fieldwork in regions of India, this article shows that trajectories of industrial restructuring and the responses by organised labour over the past two decades have been diverse. It is argued that the diverse response not only reflects structural opportunities and constraints for labour to be organised in particular ways, but also different histories and experiences of labour association. Contrary to the presumption about the general demise of trade unionism and the apparent unattainability of class solidarity in contemporary globalised capitalism, it is observed that India's labour movement is experiencing a degree of resurgence, and new forms of labour organisations and activism are emerging, especially involving informal workers in the formal sector. That these innovative forms of mobilisation are shaped by experiences and aspirations that do not conform to the established institutionalised frameworks for dispute resolution has important policy and political implications.
\end{abstract}

Keywords: class dynamics; industrial restructuring; industrial relocation; informal employment; trade unions; collective bargaining; India 
This is the Accepted Version of a forthcoming article that will be published by Taylor and Francis in Third World Quarterly: http://www.tandfonline.com/loi/ctwq20\#.V1a--vkrKM8

Accepted Version downloaded from SOAS Research Online: http://eprints.soas.ac.uk/22573/

\section{Introduction}

This article is concerned with the diversity in patterns of industrial restructuring and responses by labour in India. Through the analysis of case studies drawn from long-term fieldwork, labour's response to informalisation and production relocation are shown to have been diverse, reflecting not only the different economic and political opportunities for mobilisation, but also the particular historical experiences of association by workers ${ }^{1}$. By doing so, it engages with the wider debate on the role of labour organisations in contemporary processes of industrial restructuring, and identify emerging opportunities and constrains for labour movements in India.

Industrial restructuring in India is often attributed to neoliberalism and globalisation to varying degrees, which have compelled firms to raise productivity and competitiveness, by reducing costs, increasing 'flexibility' and strengthening control over labour ${ }^{2}$. These changes are of course not unique to India, and share elements of broader changes at the global-level associated with the 'great slowdown' of production in advanced capitalist countries since the $1970 \mathrm{~s}^{3}$. At the same time, the industrial restructuring in India, which also started in the 1970s, preceding the full scale liberalisation, has been at least in part a response to India's own 'crisis of accumulation' in the second half of the $1960 \mathrm{~s}^{4}$.

Thus industrial restructuring has been on-going in India for several decades, which has taken a variety of different forms, or 'fixes' for recovering profitability. As observed globally, these include: geographical relocation of production; changes in the organisation of production and the labour process; shifting industrial sectors and products; and the extension of financing and speculative activities replacing or subjugating production ${ }^{5}$. In the case studies analysed in this article, firms have placed increased emphasis on practices such as the intensified use of casual and contract labour and relocation of production to regions where labour movements are less well established. It has been argued that these practices reflect capital's strategy to subordinate labour, especially by impeding the right to organise ${ }^{6}$.

There has been a diversity of responses by Indian labour organisations to this industrial restructuring, including different forms and levels of mobilisation. Policy 
This is the Accepted Version of a forthcoming article that will be published by Taylor and Francis in Third World Quarterly: http://www.tandfonline.com/loi/ctwq20\#.V1a--vkrKM8

Accepted Version downloaded from SOAS Research Online: http://eprints.soas.ac.uk/22573/

debates and labour politics at the national level have primarily been focused on 'flexible' labour market reforms since the $1990 \mathrm{~s}^{7}$. The most recent version of this agenda is the labour law reforms pursued by the governing Bharatiya Janata Party (BJP). This includes measures which allow greater number of firms to operate outside the coverage of most labour legislation, and make it more difficult for trade unions to be formed and recognised as representative agents.

In response, national Central Trade Union Organisations (CTUOs) affiliated to a range of political parties and factions organised campaigns to challenge these labour law reforms at various times. India's organised labour movement has traditionally been fragmented along partisan lines since political parties attempted to formally organise workers in the $1940 \mathrm{~s}^{8}$. Until recently CTUOs have struggled to coordinate their campaign across partisan and factional lines against on-going labour law reforms. The nation-wide general strike in March 2012 was the first action in recent history called by all major CTUOs across the political spectrum, including (at the time) the ruling Indian National Congress (INC)'s affiliated labour-wing, the Indian National Trade Union Congress (INTUC), and the BJP's union organisation Bharatiya Mazdoor Sangh (BMS), which was followed up a two-day general strike in February 2013. While in the September 2015 general strike, the now ruling BJP-affiliated BMS broke ranks with other CTUOs $^{9}$, in the national protest against government proposals for labour law reforms on 10 March 2016, the BMS re-joined the action with other CTUOs. Significantly, these coordinated national actions since 2012 have involved demands for no contractualisation of permanent jobs, and equalising pay and benefits between contract and regular workers ${ }^{10}$.

If there are signs of convergence amongst CTUOs at the national level in response to the on-going challenges of labour law reforms, there are uneven but growing indications of rising unionisation ${ }^{11}$ and intensifying labour unrest ${ }^{12}$. Reflecting the continuing trend of informalisation in recent decades, increasing attempts to organise informally employed workers have been documented, including in regions and sectors where unionisation has been traditionally limited ${ }^{13}$. Much of the well-publicised and intense moments of labour unrest have involved increasingly diverse forms of labour organisations, which are not connected to established CTUOs $^{14}$. 
This is the Accepted Version of a forthcoming article that will be published by Taylor and Francis in Third World Quarterly: http://www.tandfonline.com/loi/ctwq20\#.V1a--vkrKM8

Accepted Version downloaded from SOAS Research Online: http://eprints.soas.ac.uk/22573/

This article contributes to this emerging literature by analysing the observed diversity in the trajectory of industrial restructuring and patterns of labour organisation through four case studies. In doing so, it draws attention to the divergence in forms of labour organisations and struggles at different sites of production, which are not always in concert with the labour politics at the nationallevel. Put differently, the article argues that emerging patterns of labour unrest are an integral aspect of the ongoing pattern of development in India, which have their roots in workers' experiences and aspirations cultivated outside established institutional frameworks for dispute resolutions.

This study also builds on ongoing debates on the role of the organised labour movement in contemporary global capitalist development ${ }^{15}$. In general, labour movements and unrest are observed to have followed where capital has attempted to recover profitability through various 'fixes', including by relocation of production ${ }^{16}$, but this pattern has not been automatic or uniform. This article shows that, in India, in some cases labour organisations in the 'old' sites linked their struggles with those in the relocated regions, while in others labour movements remained within agreed institutional frameworks in the region or the sector, limiting the emergence of alternative forms of labour organisation. As has been frequently observed, in sectors and regions with unfavourable structural conditions, trade unions' ability to link their plant-level struggles to broader solidarity movements, both regionally and internationally, is critical for the effectiveness of their mobilisation ${ }^{17}$. Unions' capacity to do so is shown to be founded not only on the particular opportunities and compulsion for mobilisation, but also on workers' specific experience of association ${ }^{18}$.

The remainder of the paper proceeds as follows. Section 1 sets the context for the remainder of the paper by discussing forms of industrial restructuring and their impact on labour movements and organisations observed in selected case studies drawn from the field research. Section 2 is divided into three sub-sections, and discusses the diverse responses by labour to industrial restructuring in face of different forms of industrial restructuring in their particular regional and sectoral contexts. Section 3 concludes by drawing political and policy implications. 
This is the Accepted Version of a forthcoming article that will be published by Taylor and Francis in Third World Quarterly: http://www.tandfonline.com/loi/ctwq20\#.V1a--vkrKM8

Accepted Version downloaded from SOAS Research Online: http://eprints.soas.ac.uk/22573/

\section{Contexts for industrial restructuring and labour organising in India}

The fieldwork on which this paper is based took place in 2001 and 2013-14, focusing on manufacturing factories in the organised sector. Worker's status in India is categorised across two dimensions. On the one hand, the site of employment is distinguished between organised and unorganised sectors depending on the size of employment (10 workers is the threshold for units with electricity; 20 without electricity $)^{19}$. On the other hand, workers are also categorised to be either formally or informally employed depending on whether the employer provides employment and social security benefits. In the 2011-12 National Sample Survey (NSS), it is estimated that of the 483.7 million Indian workforce, 91.9 percent were informal workers. Of course, the two dimensions tend to overlap: of those employed in the unorganised sector, 99.6 percent were categorised as informal workers ${ }^{20}$.

Informalisation has been a structural characteristic of India's labour market since early industrialisation in the mid-nineteenth century under British colonial rule ${ }^{21}$. In recent decades, informalisation has proceeded not only through the expansion of the unorganised sector, but also increasingly by the informalisation of employment practices within the organised sector ${ }^{22}$. In the 1999-2000 NSS data, 62.2 percent of those employed in organised sector units were categorised as formal workers. In 2011-12, this figure fell to 45.4 percent, indicating that the majority of those employed even in the organised sector is now estimated to be working without employment and social security benefits. The period of this research has coincided with the increased use of subcontracting and casual employment in formal/ organised sector firms, which as noted above, are associated with the on-going industrial restructuring since the 1970s.

Along with the informalisation of employment, another important consequence of industrial restructuring and a backdrop to the present field research has been the relocation of production away from traditional industrial centres, such as Kolkata (Calcutta) in West Bengal and Mumbai (Bombay) in Maharashtra. Newer industrial centres have emerged in various parts of India over the past several decades, some of which have been in smaller cities and towns adjoining larger metropolises, as well as in rural areas in the same States. Some industrial production has also shifted to 
This is the Accepted Version of a forthcoming article that will be published by Taylor and Francis in Third World Quarterly: http://www.tandfonline.com/loi/ctwq20\#.V1a--vkrKM8

Accepted Version downloaded from SOAS Research Online: http://eprints.soas.ac.uk/22573/

regions with a less established history of industrial development and organised labour, including Gujarat and the National Capital Region (NCR) ${ }^{23}$. This shifting pattern in India's industrial location has been further reinforced by the decline in the labour migration in-flows to traditional major industrial centres and cities such as Kolkata and Mumbai in favour of the above mentioned newer sites in recent years ${ }^{24}$.

[Figure 1]

This industrial relocation - or 'spatial fix' - is reflected in the evolution of the present research, mapped in Figure 1. In 2001, fieldwork was carried out in a total of 20 mills and factories in a wide variety of industrial activities, ranging from jute and cotton textiles to light engineering and pharmaceuticals, all based in two cities, Kolkata and Mumbai. In the recent round of fieldwork in 2013-14, many of the units surveyed in 2001 either terminated or relocated production to other sites ${ }^{25}$. In all cases where production was relocated, the destination was to regions with a limited history of organised labour and where the enforcement of labour law has been lax. Follow-up research has been carried out at new units where production was relocated, which meant that subsequently the fieldwork extended beyond the original two cities to include other regions such as Pune and rural areas in the Buldhana District within Maharashtra; its neighbouring State of Gujarat and Union Territory of Dadra and Nagar Haveli; the National Capital Region (NCR) in north India; and further north in Chandigarh intersecting Himachal Pradesh and Uttarkhand.

[Table 1]

Rather than analysing all cases studied during the two rounds of fieldwork ${ }^{26}$, this article focuses on four selected cases representing different ways in which labour has responded to industrial restructuring, as outlined in Table 1. In all four cases, informalisation of employment by increased use of casual and contract labour, as well as intensification of the labour process were observed. All cases involved some degree of relocation of production to or within newer industrial areas with less established histories of labour movements, and two of these involved the closure of the original plants. These features correspond to some aspects of the so-called 'low road' of industrial restructuring, where improvements in productivity and competitiveness are achieved primarily through an enhancement of 'numerical 
This is the Accepted Version of a forthcoming article that will be published by Taylor and Francis in Third World Quarterly: http://www.tandfonline.com/loi/ctwq20\#.V1a--vkrKM8

Accepted Version downloaded from SOAS Research Online: http://eprints.soas.ac.uk/22573/

flexibility', lowering labour costs and the intensification of work $^{27}$. However, some of the cases also involved technological change in the production process as well as in the products manufactured, with degrees of 'flexible specialisation', which are features of 'high road' strategies in restructuring ${ }^{28}$. Therefore, although informalisation of employment and relocation of production feature in these case studies, they do not represent a simplistic perpetuation of the 'race to the bottom' thesis ${ }^{29}$. This is because although the cases selected belong to the so-called 'high end' sectors, they manufacture standard products with standardised production processes where profit margins are small ${ }^{30}$.

Both informalisation of employment and relocation of production have had significant implications for labour organisations and movements. India's Trade Union Act of 1926 applies to organised sector units, and in theory, workers are entitled to form or join a trade union regardless of whether they are formally or informally employed. In practice, unionisation of informal workers has faced challenges in India, sometimes due to legal interpretations of the employer-employee relation ${ }^{31}$, but more generally due to employers' refusal to recognise informal workers as a representative agent for collective bargaining. The latter is compounded by the Trade Union Act not stipulating the compulsory recognition of representative unions by employers or procedures for such recognition. The Industrial Disputes Act of 1947, which provides legal procedures for dispute resolution, also only applies to the organised sector, and typically to permanent or regular employees. Therefore, informalisation of employment in the form of subcontacting and casualisation not only potentially erodes the organisational base for trade unions, but also limits the legal and institutional recourse available during industrial disputes.

The lack of national-level legal stipulation for employers to recognise representative unions has led to diverse developments in labour organisations across regions in India. This is partly because trade unions and industrial disputes are on the 'concurrent' list, which allows state governments to amend central government Acts or issue separate legislation, and also because the legislation are enforced at the statelevel. The regional diversity is important because different institutional frameworks for labour bargaining can impact on the 'tightness' of the labour markets, and thus affect workers' 'marketplace structural power' ${ }^{32}$. It also has implications for 
This is the Accepted Version of a forthcoming article that will be published by Taylor and Francis in Third World Quarterly: http://www.tandfonline.com/loi/ctwq20\#.V1a--vkrKM8

Accepted Version downloaded from SOAS Research Online: http://eprints.soas.ac.uk/22573/

opportunities and constraints for labour to respond differently to industrial restructuring, as well for workers' capacity and experience in various forms of labour associations.

Of the industrial units studied in the present research, many in Kolkata have had multiple representative unions recognised in a single workplace, typically affiliated to different political parties and factions ${ }^{33}$. The most dominant of these party-affiliated union organisations in West Bengal, where Kolkata is located, is the Centre for Trade Unions (CITU), the trade union wing of the Communist Party of India-Marxist (CPM), which governed the state between 1977 and 2011. In 2011, a coalition led by the All India Trinamool Congress was elected to power, but at the time of the fieldwork in 2013-14, the CITU-affiliated unions continued to be influential in many workplaces. Interestingly, despite being critical to the CPM-CITU nexus, there are indications that the All India Trinamool Congress is cultivating a similar institutional network for the organised labour mobilisation under its own labour arm, the Indian National Trinamool Trade Union Congress (INTTUC). It does this, either by setting up a rival affiliated union or replacing the existing CITUaffiliated leadership in the workplace studied ${ }^{34}$. The continued dominance of partyaffiliated unionism in Kolkata so far is an indication that organised labour continues to retain some degree of importance for political parties in the region.

By contrast, Mumbai's Maharashtra has been led by a combination of the Indian National Congress (INC) and the Nationalist Congress Party (NCP) - the NCP split from the INC in 1999 - for much of the period since independence until 2014, when the coalition led by the Bharatiya Janata Party (BJP) formed the government. In sectors such as textiles, the INC has imposed the union affiliated to its labour-wing, the INTUC, as the sole representative union based on the provision of the Bombay Industrial Disputes Act of 1946. However, in general, the INC took steps to 'demobilise' the labour movement following independence, containing communist trade unions and restraining labour militancy ${ }^{35}$. The subsequent rise of communalbased redistributive politics ${ }^{36}$ has further diminished the political influence of partyaffiliated trade unions in Mumbai. Significantly, Congress-affiliated unions, as well as the Shiv Sena's labour wing Bharatiya Kamgar Sena (BKS) and today's governing BJP's the Bharatiya Mazdoor Sangh (BMS), have traditionally sided with the 
This is the Accepted Version of a forthcoming article that will be published by Taylor and Francis in Third World Quarterly: http://www.tandfonline.com/loi/ctwq20\#.V1a--vkrKM8

Accepted Version downloaded from SOAS Research Online: http://eprints.soas.ac.uk/22573/

government and employers, and often attempted to undermine labour struggles by others, particularly those by leftist unions.

The ineffectiveness of party-affiliated unionism has opened space for diverse forms of independent unionism in Mumbai $^{37}$, ranging from non-party affiliated federations to company unionism, as well as involvement of civil society organisations representing workers' causes. In general, forms of labour organisation have been more diverse in Mumbai compared to Kolkata, and as a result, labour disputes have been less prone to institutional mediation by political parties and the state. While state-mediated frameworks for dispute resolution are sometimes favoured on the grounds that they are associated with 'restrained' labour militancy and industrial peace ${ }^{38}$, it is also observed that conciliated settlements tend not to be in favour of workers ${ }^{39}$. It is argued in section 2 that the contrasting historical unfolding and experience of association in the two cities contributed to different patterns and trajectories of labour responses in the case study factories.

In each of the cases studied, industrial relocation or 'spatial fixes' were always accompanied by other forms of 'fix', such as transformation of the labour process, changes to the product, and the extension of financial activities, all of which have implications for the shifting boundaries of employment status and labour's 'structural' as well as 'associational power' to organise ${ }^{40}$. For example, outsourcing and subcontracting can undermine the strategic location of a workforce in the production process, and also reduce the capacity for workers in different segments to coordinate their struggles ${ }^{41}$, as shown in the case of the electronic fan manufacturing in section 2.1. Relocation of production to regions with greater unemployment and underemployment reduces workers' bargaining power in the labour market in general. It may also undermine workers' capacity for association, especially when production is relocated to areas with a limited history of unionisation, as in the two cases discussed in section 2.2.

One of the ways in which labour can respond to the relocation of production is by coordinating struggles across geographical locations ${ }^{42}$. In the cases analysed below, two types of extra-plant institutions can be identified. The first is the traditional statemediated collective bargaining framework typically set up at the industry-level. This type of tripartite labour institution continues to provide the platform for wage 
This is the Accepted Version of a forthcoming article that will be published by Taylor and Francis in Third World Quarterly: http://www.tandfonline.com/loi/ctwq20\#.V1a--vkrKM8

Accepted Version downloaded from SOAS Research Online: http://eprints.soas.ac.uk/22573/

settlements in the textile industry. In the case of the electronic fan factory in Kolkata discussed in section 2.1, although the collective bargaining has decentralised to the plant-level, wages are still calculated using the pay-scale agreed under a tripartite settlement last negotiated in 1997. The second type of extra-unit institution is the union federation or network organised as an association of workers ${ }^{43}$. This means that independent union organisations unaffiliated to political parties can be organised at workplace-levels, but also they can form federations linking these plant unions. Indeed, a company-wide union federation at the soap and detergent corporation played an instrumental role in linking struggles at various sites. This is contrasted in section 2.2 with another case of relocation of production at a company manufacturing luminary products, where an extra-plant company union federation collapsed, weakening the capacity for workers to form a union at the relocated production site.

The diverse responses by labour to industrial restructuring reflects the range of opportunities and compulsions for workers to organise, which are shaped by the articulation of a range of factors, such as labour law, the nature of labour politics, and the ways in which changes in employment practices and the relocation of production affect the 'structural power' of workers. Crucially, the diversity of labour's responses also reflect particular histories of labour organisation and worker experiences of association. The final case discussed in section 2.3 , the automobile assembly plant in the NCR, contrasts with the other three cases (see Table 1) in that the production site was set up in a newer industrial area, hiring migrant workers with limited connections to the region, but also limited experience in conventional forms of labour organisation. It is argued that the intense struggle and the particular form of unionisation pursued at this unit reflect the different aspirations of workers, as well as the limited and weaker experiences in institutionalised forms of labour protest in the region.

\section{Diverse dynamics of industrial restructuring and labour organising in India}

This section is divided into three sub-sections, analysing four cases of industrial restructuring and labour movements drawn from the field research. Section 2.1 focuses on an electronic fan manufacturing plant based in Kolkata, where the response by organised labour has been limited despite significant changes to the product, production organisation and labour process. This is contrasted with cases 
This is the Accepted Version of a forthcoming article that will be published by Taylor and Francis in Third World Quarterly: http://www.tandfonline.com/loi/ctwq20\#.V1a--vkrKM8

Accepted Version downloaded from SOAS Research Online: http://eprints.soas.ac.uk/22573/

from Mumbai-based luminary and soap and detergent firms in section 2.2 in which union federations and extra-plant solidarity movements played an important role in determining unions' capacity to link struggles. Finally, section 2.3 examines a case of auto assembly that emphasises the challenges associated with unionisation in newer industrial regions with less established institutional frameworks for labour organisations.

\subsection{Industrial restructuring and organisation of labour in Kolkata: the case of electronic fan manufacturing}

One of the production sites surveyed in Kolkata is a leading manufacturer of electronic fans and has been operating since the 1950s. Until the early-1990s most manufacturing and assembly processes were carried out in-house at the plant, but over the past thirty years all manufacturing and a number of assembly tasks have been shifted to outside vendors, leaving only part of assembly, quality inspections and final packaging on site. The company has another plant in the NCR in north India, which retains some of the manufacturing and assembly processes. The NCR plant is reported to employ primarily migrant workers who are not unionised, and who the company management alleges are more willing to accept 'flexible' working schedules according to the seasonality of demand in the product.

This change in production organisation accompanied a significant shift in workforce composition at the Kolkata plant. In 2001, when the plant was initially surveyed, it was reported that the majority of 357 workers employed had permanent contracts. By 2013, only 79 workers had permanent status on the payroll but the company had 487 contract workers organised by 14 contractors working on site. Some of the contract workers were hired to carry out tasks such as catering and cleaning, but most of them were working on the assembly line, sometimes alongside permanent workers. Some contractor groups had exclusive responsibility forcertain tasks, including one that specialises in the assembly of motors, a core task in the manufacturing of electronic fans. Workers from this latter contractor are said to assemble one motor every 12 seconds, or about 300 motors per hour per person, which the company management alleges is 30 per cent more than can be achieved by workers in other groups, including permanent workers. 
This is the Accepted Version of a forthcoming article that will be published by Taylor and Francis in Third World Quarterly: http://www.tandfonline.com/loi/ctwq20\#.V1a--vkrKM8

Accepted Version downloaded from SOAS Research Online: http://eprints.soas.ac.uk/22573/

These changes in production organisation coincided with the rising demand for electronic fans and technological change in the material used, with plastic replacing some of the metal parts. As the plant did not have facilities to manufacture these plastic parts, the company started to outsource production fromthe early-1990s. The shift to plastic enabled fans to be made lighter and designed in greater accordance with consumer preference. Furthermore, the reduction in the reliance on the permanent workforce allowed the company to gain greater control over the production costs, by smoothing the cost of parts and components procurement as well as lowering labour costs. However, despite the increased use of outsourcing and contractors, the management in the Kolkata plant expressed an inability to adjust the workforce in response to seasonal variation in demand compared to the NCR plant.

Despite the significant change in the labour process as a result of the 'spatial', 'technological' and 'product' fixes, explicit labour unrest or resistance have been limited at this plant in Kolkata. Since the initial fieldwork in 2001, there have been three unions active at this site: one affiliated to the CPI-M's CITU, one belonging to a State-level faction of the INC, and another independent union without formal affiliation to political parties, although the leadership was linked to the BJP. At the time of the 2013 fieldwork, a fourth INTTUC-affiliated union was set up, reportedly becoming the preferred union of the company management after the rise to power of the All India Trinamool Congress in West Bengal. All four of these recognised unions only represented permanent workers, collectively negotiating pay settlements every three years. However, at the time of the research, there was an attempt by some contract workers to form a separate union, which was resisted by the company and apparently unsupported by the existing unions.

This represents a case in which, despite significant industrial restructuring, changes to the organisation of labour and overt labour unrest have been limited. It is possible, however, that subtler forms of struggle take place in collective bargaining. Although wages are indexed to the pay scale negotiated at industry-level in 1997, it is likely that unionised workers gain a greater degree of employment security and various fringe benefits, such as paid leave during festival period. The management's complaint about 'inflexible' labour in the Kolkata plant compared to the newer NCR site also hints that unionised labour in Kolkata is not without bargaining power. 
This is the Accepted Version of a forthcoming article that will be published by Taylor and Francis in Third World Quarterly: http://www.tandfonline.com/loi/ctwq20\#.V1a--vkrKM8

Accepted Version downloaded from SOAS Research Online: http://eprints.soas.ac.uk/22573/

But these gains are negotiated and allowed, in so far as workers operate within the institutional framework set by the company, trade unions, and political parties. Political parties use their affiliated unions not only to mobilise votes and organise rallies, but also as a means of 'restraining' labour militancy and maintaining a conducive environment for accumulation ${ }^{44}$. Indeed, contrary to the popular perception of party-affiliated unionism being a hindrance to attracting investment in West Bengal, factory managers interviewed in the present research often expressed their preference for a unionised workforce that can be 'disciplined' with the help of political parties or the state. In a broader historical perspective, state accommodation of organised labour in West Bengal might also be in response to class struggle in a context in which classbased political mobilisation has relatively greater political influence. Nevertheless, in relation to the present discussion, the dominance of party-affiliated unionism appears to have offered limited opportunities and incentives for, as well as capacities of workers to respond to the on-going industrial restructuring through alternative forms of labour organisations. Unions independent of political parties and organisations external to the firm have been less prominent in Kolkata compared to other regions in cases studied for this research (particularly Mumbai). It is also significant that the unionisation of the non-permanent workforce has been limited both in its attempt and in any success, in contrast to the cases discussed below.

\subsection{Industrial restructuring and the role of union federations: a comparison of two Mumbai-based firms}

\section{The case of luminaries manufacturing}

As part of the initial research design, several firms were selected for operating similar production in Kolkata and Mumbai in $2001^{45}$. One of these was a multinational electronics company producing light bulbs and luminary products in the two cities with similar production organisation and technology. While 144 workers, most of whom were permanent, at the Kolkata plant were organised by a CITU affiliated union, 245 again mostly permanent workers at the corresponding unit in Mumbai were represented by a plant-based company union unaffiliated to political parties. The latter union at the Mumbai's production unit was formed in the late 1960s, which subsequently linked with unions in other units of the company to form an India-wide enterprise union federation in 1971. The role of the union federation at this electronics company was to demand equalisation of bonus payments and pension 
This is the Accepted Version of a forthcoming article that will be published by Taylor and Francis in Third World Quarterly: http://www.tandfonline.com/loi/ctwq20\#.V1a--vkrKM8

Accepted Version downloaded from SOAS Research Online: http://eprints.soas.ac.uk/22573/

schemes for workers across different establishments in India. Although the company was unwilling to negotiate with the union federation at the beginning, preferring to negotiate different settlements at each unit, it finally gave recognition in 1979.

By the mid-1980s the union federation was becoming ineffective, collapsing in 1986. This was alleged to have been a result of an emerging conflict of interest between units. In 1982 the head office union in Mumbai refused to sign the settlement negotiated by the federation demanding a higher bonus for their staff. In a subsequent case, divisions emerged between units over the company's attempt to introduce computers in offices, eventually exposing the inability of the federation to control plant-level union bodies. However, the company management also actively sought to instigate the split within the union movement, by encouraging supervisors to join a management-sponsored staff union set up in all units around 1985-86.

Union activists claim that the attempt to undermine the India-wide union federation was part of the wider company strategy, which was formed around the same period, to reorganise offices and production facilities away from the traditional industrial centres to regions with less established organised labour. A company executive, in an interview, argued that political conditions in Kolkata and Mumbai 'that give workers what they want', and which 'keep employees in comfort zone and give rise to complacent employment relations' were the reason to close these units and shift production to regions with a 'higher level of efficiency'. The company eventually closed both the Kolkata and Mumbai units in the mid-2000s, setting up two new plants, one in a rural area in the outskirts of Vadodara in Gujarat and another in a remote part of Chandigarh in north India. The company decided that the latter plant would specialise in manufacturing energy-efficient light bulbs and lamps, which involves use of more up-to-date machinery and technology, with the conventional light bulb and lamp production to be consolidated in Gujarat. The production at the Vadodara unit started with machinery taken from the closed plants, with some workers also being brought to the new facility to train the workers.

According to union activists, there was an initial attempt by a regional independent union to organise workers at the Vadodara plant, but the company refused to recognise the union, partly due to its association with the union at the company previously active at the same site. Around ten workers who were considered 
This is the Accepted Version of a forthcoming article that will be published by Taylor and Francis in Third World Quarterly: http://www.tandfonline.com/loi/ctwq20\#.V1a--vkrKM8

Accepted Version downloaded from SOAS Research Online: http://eprints.soas.ac.uk/22573/

to have had links with the union lost their jobs and other union activists were forced to go underground. Until 2012, no recognised unions were present at the plant, but when issues that needed settling arose, the management instigated a 'workers' committee', which union activists allege was 'pseudo-management doing the task of the company' even though it was run by workers. After several attempts to set up unions at the plant, in 2012 the management recognised an independent plant-based union entirely of rank-and-file workers, with no links to external organisations. A company executive admitted in an interview that management demanded the union at Vadodara to have no contacts with those involved in the previous union federation at the closed plants. It is particularly significant that the relocation to Gujarat did not result in a nonunionised 'flexible' labour regime, as popularly assumed. The leadership of this new internal union is based on the previous 'workers' committee' at the plant, prompting activists external to the company to criticise it as a 'management's union', although the union leaders themselves are keen to disassociate themselves from this image.

\section{The case of soap and detergent manufacturing}

Contrast this with another case of industrial relocation from Mumbai, which took place at the oldest plant of a multinational consumer goods company dating back to the 1930s, manufacturing soaps, detergents, chemicals and personal care products. In 2001, around 2,000 workers were represented by an independent company union. Similarly to previous cases, the company formulated a strategy to close down facilities in traditional industrial centres and to shift production to remote areas with less established labour institutions. The Mumbai plant eventually closed down in the mid-2000s, but as early as 1988 soap manufacturing started to shift to Khamgaon, located in north east Maharashtra, and detergent production shifted in 1998 to Dadra and Nagar Haveli, a central-government controlled Union Territory bordering Maharashtra and Gujarat. Manufacturing of personal products shifted to Chandigarh in north India after the closure of the Mumbai site.

As with the case of the luminaries company, the Mumbai union at the soap and detergent company also linked up with unions at other plants of the company to form an all-India enterprise union federation. However, unlike in the former case, the federation did not act as a bargaining body for settlements, with the company continuing to hold separate agreements in each plant, and in the case of the Mumbai 
This is the Accepted Version of a forthcoming article that will be published by Taylor and Francis in Third World Quarterly: http://www.tandfonline.com/loi/ctwq20\#.V1a--vkrKM8

Accepted Version downloaded from SOAS Research Online: http://eprints.soas.ac.uk/22573/

plant even negotiating separate deals with soap and detergent departments. The federation acted more as a platform to build solidarity and resources for unions under the company, and continues to actively engage in extra-unit issues. Both the Khamgaon and the Dadra and Nagar Haveli plants have internal unions with links to the company's union federation, although the Khamgaon union is also affiliated to the BJP's union organisation BMS, while the Dadra and Nagar Haveli union is linked to the CPM's CITU. Thus, the company union federation was instrumental in maintaining solidarity amongst plant-level unions located across different regions, engaged in different products and production processes, and with different affiliations. The federation has also been successful in linking local-level struggles over various issues, including outsourcing and subcontracting, workplace safety, and further relocation of production. Despite their attempts to bring contract workers into their organisation, none of the unions have formally represented contract workers. However, the federation has campaigned for regular and contract workers to be treated equally in terms of pay and working conditions.

At the same time, in all cases observed in this research, the process of industrial relocation has been associated with attempts to weaken workers' associational power and gain greater control over the organisation of work. In the example of the consumer goods firm, management continued in its attempt to undermine union leadership with links to the federation. In 2003, management at the Dadra and Nagar Haveli site brought in a rival union, affiliated to the external industry-wide Association of Chemical Workers Union (ACW), and despite the internal federation-affiliated union claiming to have majority support, negotiated a settlement with this 'yellow' union. The internal union filed a case with the Statelevel Court, but the company continued to recognise only the ACW-linked union leaders and negotiated another settlement with them in 2007 when disputes occurred over the shifting of production between plants within the area. This situation continued until 2010, when the ACW finally walked away from the plant, and in the 2012 settlement the federation-linked union acted as the representative of workers. However, at the time of the study in 2014, the fractious relation between the management and the internal union was continuing, with the unit secretary dismissed the previous year. 
This is the Accepted Version of a forthcoming article that will be published by Taylor and Francis in Third World Quarterly: http://www.tandfonline.com/loi/ctwq20\#.V1a--vkrKM8

Accepted Version downloaded from SOAS Research Online: http://eprints.soas.ac.uk/22573/

In an even starker case, after several years of legal disputes over safety measures at the plant, the entire union leadership at the Khamgaon site linked to the federation was removed by the management in 2013, forcing workers to sign documents declaring allegiance to the new company-approved leadership. At the time of the 2013-14 fieldwork, ejected leaders were still legally challenging the company's conduct and the legitimacy of the installed union leaders, supported by donations from workers at the unit and the wider union federation.

The intensity with which the company management has attempted to undermine the federation-affiliated plant-level unions indicates the extent to which their 'associational power' is enhanced by the extra-plant solidarity. The company union federation has developed in recent years beyond linking organised labour within this multinational soap and detergent company, and started to cultivate access to international organisations and diplomatic communities. For example, when the negotiations over the voluntary retirement scheme (VRS) of the closed Mumbai plant stalled, the union federation sent a letter to the Organisation for Economic Cooperation and Development (OECD) documenting the company's unwillingness to follow up on the compensation agreed before the plant closure. As the company's headquarters are in an OECD country, its High Commission in Mumbai was called in to mediate the negotiation and avoid further negative publicity. The union federation has since been utilising similar tactics in contesting the company's union busting policies and inchallenging its workplace safety records. The union federation's link to global solidarity movements has further been strengthened by retrenched leaders of the closed Mumbai plant recently taking up roles as the Indian representative of one the largest global union federations, which has given them another channel to link labour struggles beyond the company. For example, the federation succeeded in regularising sections of contract workers in one of the affiliated units in north India.

The case of the soap and detergent company, where the federation was retained as a loose umbrella organisation of plant-level unions, including at the relocated sites, contrasts with that of the luminary product firm, where its India-wide union federation collapsed. The company management at the latter was successful in resisting unionisation in the relocated plant in Vadodara for nine years, and only 
This is the Accepted Version of a forthcoming article that will be published by Taylor and Francis in Third World Quarterly: http://www.tandfonline.com/loi/ctwq20\#.V1a--vkrKM8

Accepted Version downloaded from SOAS Research Online: http://eprints.soas.ac.uk/22573/

allowed it under the condition that those previously involved in the union federation would not interfere.

The production process represented in these two cases involves final 'downstream' stages of standardised consumer goods manufacture, and therefore the difference in workers' structural 'workplace bargaining power' accrued from their strategic location is unlikely to be significant. Also, the regions where production has been relocated in both cases are newer industrial areas with an abundant labour supply, either from the surrounding rural areas or in-migration from other States, and therefore the difference in 'marketplace bargaining power' may also limited. What distinguishes these two cases is the different history and experience of extra-plant union federations, which link workplace struggles at different sites and allow for solidarity to be developed, enabling the cultivation of 'associational power'. The final case study further highlights the importance of the historical experience of association, as well as the issue of contract labour, to which we now turn.

\subsection{Organising labour in a newer industrial area: the case of an automobile assembly plant}

The national capital region (NCR) in the suburbs of Delhi has been the site for some of the most intense labour unrest in India over the past decade ${ }^{46}$. One of the units surveyed in the present research is a multinational automobile company, which set up its first plant in the mid-1980s in Gurgaon, at which a union initially affiliated to the ruling INC's INTUC represented permanent workers. The labour unrest in 2000 at the old Gurgaon plant saw the State government intervene. The entire union leadership was subsequently dismissed, replaced by a new leader who delinked its party-affiliation. In 2006, the company set up its second plant in Manesar also in the NCR, only 30 kilometres from the first Gurgaon site. At the time of the 2013-14 fieldwork, there were 1,054 permanent workers and around 2,600 regularly employed contract workers at the new Manesar plant.

In 2011, dissatisfied with the intensity of work and levels of pay and benefits, workers at the new Manesar plant started to mobilise to form their own union. The company initially suppressed this move citing fear of union affiliation to political parties. Instead of setting up their own union, the company insisted that they join the existing independent union at the old Gurgaon plant, which the workers refused. 
This is the Accepted Version of a forthcoming article that will be published by Taylor and Francis in Third World Quarterly: http://www.tandfonline.com/loi/ctwq20\#.V1a--vkrKM8

Accepted Version downloaded from SOAS Research Online: http://eprints.soas.ac.uk/22573/

During a 10 month dispute, the company used various means of intimidation, including terminating the contracts of workers demanding unionisation, undeclared lockouts, deployment of police and company-hired 'goons', and threat of torture and imprisonment. Workers responded with several phases of wildcat strikes and sit-down protests $^{47}$. In March 2012, a new independent union based in Manesar was registered with the State government. However, later in 2012, an incident occurred which led to the murder of a human resource manager and the injury of several others. While the new union leadership pointed to suspicious circumstances which indicate collusion between the company management and the police, 147 workers were arrested, followed by a suspension of 546 permanent workers and 1,800 contract workers. The union's activity shifted to supporting the suspended and arrested workers, which attracted international solidarity. This led to a formation of an international delegation of lawyers, trade unions and human rights groups to investigate the incident, which included a trade union leader from the parent automobile company ${ }^{48}$. In 2014 the first union election was held at the Manesar plant after the incident, in which the previous leadership held on to their posts, and the arrested workers received bail in 2015. The union continues to lead the campaign to reinstate the dismissed workers as well as for equalisation of pay between permanent and contract workers.

As with the two cases discussed in section 2.2, auto production in NCR represents another example of eventual unionisation in a newer industrial area with less established labour movements. This case is particularly significant in that the process of unionisation was based on rank-and-file mobilisation, as opposed to leadership approved by the company management as in the luminary plant. It is also important to note that, although the newly formed union in the Manesar plant is officially based on members who are permanent workers, a key demand of the union from its outset was for all contract workers to be regularised and to receive the same pay and benefits. Even though this demand has not been fulfilled, and the company has further outsourced and subcontracted production processes since the formation of the union, the solidarity formed between regular and contract workers has been an important basis of its mobilisation, and contrasts with the Kolkata electronic fan plant in section 2.1 . 
This is the Accepted Version of a forthcoming article that will be published by Taylor and Francis in Third World Quarterly: http://www.tandfonline.com/loi/ctwq20\#.V1a--vkrKM8

Accepted Version downloaded from SOAS Research Online: http://eprints.soas.ac.uk/22573/

The automobile industry is seen as one of the sectors where vertical linkages offer structural 'workplace bargaining power' due to workers' capacity to disrupt production $^{49}$. A certain degree of education and skill training are required, which might also offer 'marketplace bargaining power', but the ease with which the company has responded to strikes and protests by bringing in replacement workforce indicates that this may be limited.

Another important aspect of this case is the experience of labour struggle and association. Like other cases analysed in this article, the NCR plants have seen increasing informalisation of employment and intensification of the labour process, which has included extension of the working day throughunpaid overtime and the cutting of meals and bathroom breaks. The imposed wage structure carries a greater component of 'performance-based' pay, which union activists claim are discretionary and often withdrawn for subjective reasons. Significantly, these processes have taken place in the context in which institutional frameworks for labour protests and dispute resolutions have been less established. Over the past decade growing labour unrest has been reported in the region, not only in the automobile sector, but also in other industries ${ }^{50}$. Unions in the NCR have established a coordinating committee to link these plant-level struggles and cultivate solidarity amongst them. The incident at the Manesar plant discussed above has also inspired solidarity actions not only within the NCR, but across India and beyond, as indicated by the formation of the international delegation.

An added element to this experience of labour association is the background of the workers at Manesar. Workers at the Manesar plant, and indeed the union leadership, are younger compared to those in other regions, mostly in their 20 s and early 30s, and are better educated. Indeed, Manear workers refused to join the existing union at the Gurgaon plant, not only because of their suspicion that the union leadership is too close to the company management, but also because of the perception that the Gurgaon workers are more 'mature, ${ }^{51}$. It is also reported that, while 60 to 70 percent of the workforce were drawn from neighbouring rural areas in 2011-12, by the time of the fieldwork in 2013-14, about 60 percent were migrants from a wide range of regions, including Orissa, Rajasthan, Himachal Pradesh, Uttar Pradesh and Bihar ${ }^{52}$. That the workers and union leaders came into labour 
This is the Accepted Version of a forthcoming article that will be published by Taylor and Francis in Third World Quarterly: http://www.tandfonline.com/loi/ctwq20\#.V1a--vkrKM8

Accepted Version downloaded from SOAS Research Online: http://eprints.soas.ac.uk/22573/

associations with different experience and aspirations, and that their recourse to established institutional frameworks of dispute resolution was limited significantly shaped the particular trajectory of labour's response in this case.

\section{Concluding discussion}

Contrary to the general perception that industrial restructuring leads to a diminished role for the organisation of labour, this article demonstrates the diverse ways in which labour has responded to industrial restructuring and various 'fixes' attempted by capital. These selected cases obviously do not diminish the challenge faced by the labour movement in India where the vast majority of its workforce is not unionised $^{53}$. But the recent increase in labour unrest, certainly in its intensity, if not in frequency ${ }^{54}$, as well as the possible resurgence of unionisation observed by macrolevel indicators ${ }^{55}$ are consistent with the findings of this study. The case studies discussed also suggest the possible opening of spaces for new forms of labour organisation and activism are emerging.

The case studies show that labour's responses have differed partly due to economic and political opportunities and compulsions for labour to be organised in specific ways. The case of the electronic fan manufacturer in Kolkata discussed in section 2.1 suggested that incumbent workers may have secured some gains in the form of employment security and fringe benefits. But the case also indicates that the dominance of party-affiliated trade unions may have limited the scope for alternative forms of mobilisation and ensured that unrest remained within the 'accepted' institutional framework, which limited the ability of recognised unions to support the formation of nascent contract worker unions.

In contrast, emerging patterns of labour unrest represented in sections 2.2 and 2.3 show that opportunities for workers to organise and mobilise on their own terms tend to be associated with their capacity to link plant-level struggles to extra-plant movements. Unions' capacity to do so partly reflected workers' 'structural' bargaining power accrued from the labour market conditions and their strategic location in the production process. But another element that shaped the diverse trajectories and patterns of labour organisation was the history and workers' experience of different forms of association. The experience of work intensification 
This is the Accepted Version of a forthcoming article that will be published by Taylor and Francis in Third World Quarterly: http://www.tandfonline.com/loi/ctwq20\#.V1a--vkrKM8

Accepted Version downloaded from SOAS Research Online: http://eprints.soas.ac.uk/22573/

and repression in isolated workplaces are brought together by dynamic and innovative modes of labour struggle, typically outside established institutional frameworks for dispute resolutions ${ }^{56}$.

The policy and political implications of this research is that the significant diversity in forms and intensity of labour movements and unrest is a reflection as well as an integral part of the ongoing processes of development and transformation in the Indian economy. Significantly, labour unrest such as those discussed in section 2.3 also have an impact on employers and policy makers. During the 2013-14 fieldwork, many company managers expressed concerns about the emerging patterns of labour unrest by 'younger workers'. A manager of a major company in Mumbai admitted that this was a consequence of Indian managers taking 'less care of unions and lost contact with workers'. A manager at another major company described some of the high profile labour unrest in the NCR as a 'turning point' and identified the contract labour issue as 'something for society to take care of'. In 2013, the now-disbanded Planning Commission of the central government organised a panel of major corporations, employer associations, CTUOs as well as other union federations to negotiate 'guidelines' and 'norms' for employing contract labour ${ }^{57}$, although the initiative appears to have ended with the BJP replacing INC at the May 2014 election. Yet, the BJP, in its election manifesto, declared labour as the 'pillar of our growth', and suggested labour law reforms as one of the means to promote a 'harmonious relationship between labour and the industry' and to encourage employers and employees to embrace the concept of 'industry family' ${ }^{58}$. In concert, elements of Indian capital, at least those represented in the Confederation of Indian Industry (CII), started to promote a 'business-labour partnership' and 'to create the conducive environment to facilitate harmonious relationship ${ }^{, 59}$. Only time and social struggle will tell whether these claims by the BJP and the CII are simply hollow populist rhetoric or reflect a changing balance of social forces.

Attempts by the established CTUOs, corporations and policy makers to negotiate an institutional framework that furnishes a stable condition for further intensified use of casual and contract labour, as implied in the on-going debates on labour law reforms are unlikely to satisfy the aspirations of a new generation of labour activists who have been shaping the emerging modes of labour struggles. The isolated 
This is the Accepted Version of a forthcoming article that will be published by Taylor and Francis in Third World Quarterly: http://www.tandfonline.com/loi/ctwq20\#.V1a--vkrKM8

Accepted Version downloaded from SOAS Research Online: http://eprints.soas.ac.uk/22573/

case studies discussed in this article reflect the widening diversity of labour responses at different workplaces, but also between labour struggles at factories and the established forms of labour politics at the national-level. Whether the observed labour unrest can provide the basis for a political-economic transformation in favour of the working class ${ }^{60}$ remains dependent on the capacity of these struggles to be mobilised beyond their individual experiences.

\section{Figure 1. Map of India and fieldwork sites}

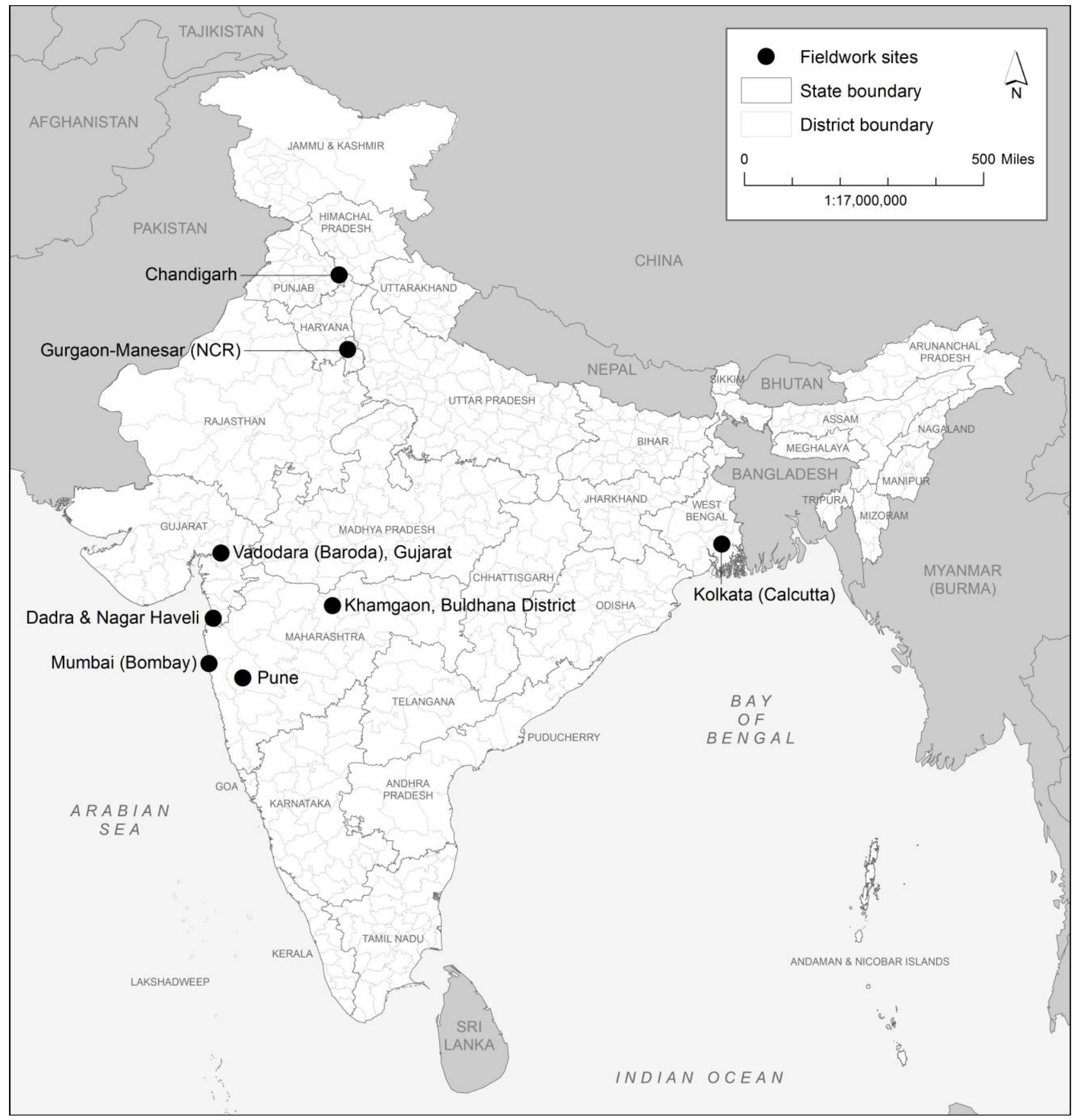

Note: Map produced by Eseld Imms. 


\section{Table 1. Four cases of industrial restructuring and labour's} response

\begin{tabular}{|c|c|c|c|c|}
\hline Section & City/ region & $\begin{array}{l}\text { Industry/ } \\
\text { product }\end{array}$ & $\begin{array}{c}\text { Type of } \\
\text { restructuring }\end{array}$ & Labour's response \\
\hline 2.1 & $\begin{array}{l}\text { Kolkata/ } \\
\text { NCR }\end{array}$ & $\begin{array}{l}\text { Electronic } \\
\text { fan }\end{array}$ & $\begin{array}{l}\text { Technological } \\
\text { change, } \\
\text { outsourcing, } \\
\text { informalisation of } \\
\text { employment, } \\
\text { intensification of } \\
\text { the labour process } \\
\text { and partial } \\
\text { relocation of } \\
\text { production }\end{array}$ & $\begin{array}{l}\text { Limited change to } \\
\text { forms of collective } \\
\text { bargaining } \\
\text { institutions and } \\
\text { labour } \\
\text { organisations. }\end{array}$ \\
\hline \multirow[t]{2}{*}{2.2} & $\begin{array}{l}\text { Mumbai/ } \\
\text { Gujarat }\end{array}$ & Luminaries & $\begin{array}{l}\text { Plant closure in } \\
\text { Mumbai and } \\
\text { relocation/ } \\
\text { consolidation of } \\
\text { production, } \\
\text { informalisation of } \\
\text { employment, and } \\
\text { intensification of } \\
\text { the labour process }\end{array}$ & $\begin{array}{l}\text { After a period of } \\
\text { resistance, } \\
\text { unionisation based } \\
\text { on management } \\
\text { controlled workers' } \\
\text { committee. Limited } \\
\text { role of the union } \\
\text { from the closed site. }\end{array}$ \\
\hline & $\begin{array}{l}\text { Mumbai/ } \\
\text { Khamgaon/ } \\
\text { Dadra \& } \\
\text { Nagar Haveli }\end{array}$ & $\begin{array}{l}\text { Soap and } \\
\text { detergent }\end{array}$ & $\begin{array}{l}\text { Plant closure in } \\
\text { Mumbai and } \\
\text { relocation. } \\
\text { Outsourcing, } \\
\text { informalisation of } \\
\text { employment, and } \\
\text { intensification of } \\
\text { the labour process. }\end{array}$ & $\begin{array}{l}\text { Union federation's } \\
\text { link maintained } \\
\text { providing basis for } \\
\text { extra-plant } \\
\text { solidarity. }\end{array}$ \\
\hline 2.3 & NCR & $\begin{array}{l}\text { Automobile } \\
\text { assembly }\end{array}$ & $\begin{array}{l}\text { New plan opened } \\
\text { due to production } \\
\text { expansion. } \\
\text { Informalisation and } \\
\text { intensification of } \\
\text { the labour process. }\end{array}$ & $\begin{array}{l}\text { After intense (and } \\
\text { on-going) struggle, } \\
\text { contract workers- } \\
\text { based unionisation. }\end{array}$ \\
\hline
\end{tabular}

\section{Acknowledgement}

The fieldwork for this research was assisted by Arpit Gaind, Joy Karmakar and Pankaj Waghmare, and funded by the Faculty Research Fund, SOAS, University of London. I am indebted to comments received by members of the Historical Materialism and World 
This is the Accepted Version of a forthcoming article that will be published by Taylor and Francis in Third World Quarterly: http://www.tandfonline.com/loi/ctwq20\#.V1a--vkrKM8

Accepted Version downloaded from SOAS Research Online: http://eprints.soas.ac.uk/22573/

Development Research Seminar (HMWDRS) and the editorial team of the special issue for this volume, in particular Jonathan Pattenden and Liam Campling who closely read this paper at several stages. I also benefitted from comments by the two anonymous reviewers, as well as participants of the Economics Department Seminar, SOAS (London) and the 44th Annual South Asia Conference (Madison, Wisconsin), where early versions of this paper were presented. The usual disclaimers apply.

\section{Contributor biography}

Satoshi Miyamura is Lecturer in the Economy of Japan at the Department of Economics, School of Oriental and African Studies (SOAS), University of London. His research interests are in the political economy of development in India and Japan; economics of labour and institutions. He is currently engaged in research drawing on fieldwork in various parts of India in 2001 and 2013-14. Recent publications include 'Rethinking Labour Market Institutions in Indian Industry: Forms, Functions and Socio-historical Contexts,' Journal of Peasant Studies, (forthcoming 2016); (with Benjamin Selwyn) 'Class Struggle or Embedded Markets? Marx, Polanyi and the Meanings and Possibilities of Social Transformation,' New Political Economy, Vol. 19 No. 5 (2014); 'Emerging Consensus on Labour Market Institutions and Implications for Developing Countries: From the Debates in India,' Forum for Social Economics, Vol. 41, No. 1 (May 2012); and 'Diversity of Labour Market Institutions in Indian Industry: A Comparison of Mumbai and Kolkata,' Indian Journal of Labour Economics, Vol. 54, No. 1 (January-March 2011).

\section{References}

Anant, T.C.A. "Labour Market Reforms in India: A Review." In Reforming the Labour Market, edited by Bibek Debroy and P. D. Kaushik. New Delhi: Academic Foundation, 2005.

Anner, Mark. "Labor Control Regimes and Worker Resistance in Global Supply Chains." Labor History 56, no. 3 (May 27, 2015): 292-307. . "Workers' Power in Global Value Chains: Fighting Sweatshop Practices at Russell, Nike and Knights Apparel." In Transnational Trade Unionism: Building Union Power, edited by Peter Fairbrother, Marc-Antonin Hennebert, and Christian Lévesque, 23-41. New York: Routledge, 2013.

Anner, Mark S. Solidarity Transformed: Labor Responses to Globalization and Crisis in Latin America. Ithaca, NY: Cornell University Press, 2011.

Aravamudan, Gita. "Can We Sit Down?" The Hindu, May 21, 2016. http://www.thehindu.com/features/magazine/gita-aravamudan-on-whetherwomen-workers-need-trade-unions-of-their-own/article8629539.ece. 
This is the Accepted Version of a forthcoming article that will be published by Taylor and Francis in Third World Quarterly: http://www.tandfonline.com/loi/ctwq20\#.V1a--vkrKM8

Accepted Version downloaded from SOAS Research Online: http://eprints.soas.ac.uk/22573/

Armstrong, Philip, Andrew Glyn, and John Harrison. Capitalism Since 1945. Oxford and Cambridge: Basil Blackwell, 1991.

Banaji, Jairus, and Rohini Hensman. Beyond Multinationalism: Management Policy and Bargaining Relationships in International Companies. New Delhi: Sage Publications, 1990.

Banerjee, Debdas. Globalisation, Industrial Restructuring and Labour Standards. New Delhi: Sage, 2005.

Bensaïd, Daniel. Marx for Our Times: Adventures and Misadventures of a Critique. London: Verso, 2002.

Bharatiya Janata Party (BJP). "Election Manifesto.” Bharatiya Janata Party, April 7, 2014.

http://www.bjp.org/images/pdf_2014/full_manifesto_english_07.04.2014.pdf.

Bhattacharya, Akash. "Challenging 'Make in India': Industrial Strikes in Gurgaon and Manesar." Economic and Political Weekly 50, no. 8 (February 21, 2015).

Bhattacherjee, D. "Organized Labour and Economic Liberalization: India: Past, Present, and Future." Labour and Society Programme Working Paper DP/105/1999. The International Institute for Labour Studies. International Labour Organization (ILO) (1999).

Bhattacherjee, Debashish. "The 'New Left', Trade Unions and Globalization in West Bengal: What Is to Be Done?" The Indian Journal of Labour Economics 44 (September 2001): 447-57.

Bhatt, Ela R. We Are Poor but So Many: The Story of Self-Employed Women in India. Oxford: Oxford University Press, 2006.

Bhowmik, Sharit K. "Cooperatives and the Emancipation of the Marginalized: Case Studies from Two Cities in India." In Another Production Is Possible: Beyond the Capitalist Canon, 2:70-94. London: Verso, 2006.

Breman, Jan. The Labouring Poor in India: Patterns of Exploitation, Subordination and Exclusion. New Delhi: Oxford University Press, 2003.

. "The Study of Industrial Labour in Post-Colonial India - The Formal Sector: An Introductory Review." In The Worlds of Indian Industrial Labour, edited by Jonathan P. Parry, Jan Breman, and Karin Kapadia. New Delhi: Sage, 1999.

Brenner, Robert. The Economics of Global Turbulence: The Advanced Capitalist Economies from Long Boom to Long Downturn, 1945-2005. London and New York: Verso, 2006.

Broad, Dave. "Globalization and the Casual Labor Problem: History and Prospects." Social Justice 22, no. 3 (61) (1995): 67-91.

Chandrasekhar, S, and Ajay Sharma. "On the Spatial Concentration of Employment in India." Economic and Political Weekly 49, no. 21 (May 24, 2014): 16-18.

Chibber, Vivek. Locked in Place: State-Building and Late Industrialization in India. Princeton, N.J.: Princeton University Press, 2006.

Chowdhury, Ashok, and Roma. "A Case Study of the National Forum of Forest People and Forest Workers' (NFFPFW) Struggle for Rights of Forest Workers," September 2009. http://wiego.org/sites/wiego.org/files/resources/files/fow_nffpfw_case_study.p df.

Confederation of Indian Industry (CII). "Engaging Contract Workforce-New Perspective on 28 Aug 2010." Media briefing. Aparajitha, 2010. http://www.aparajitha.com/engaging-contract-workforce-new-perspective. 
This is the Accepted Version of a forthcoming article that will be published by Taylor and Francis in Third World Quarterly: http://www.tandfonline.com/loi/ctwq20\#.V1a--vkrKM8

Accepted Version downloaded from SOAS Research Online: http://eprints.soas.ac.uk/22573/

Das, Raju J. "Reconceptualizing Capitalism: Forms of Subsumption of Labor, Class Struggle, and Uneven Development." Review of Radical Political Economics 44, no. 2 (June 1, 2012): 178-200.

Davies, Ronald B., and Krishna Chaitanya Vadlamannati. "A Race to the Bottom in Labor Standards? An Empirical Investigation.” Journal of Development Economics 103 (July 2013): 1-14.

D’Cruz, Premilla, and Ernesto Noronha. "Hope to Despair: The Experience of Organizing Indian Call Centre Employees.” Indian Journal of Industrial Relations 48, no. 3 (January 2013): 471-86.

Doogan, Kevin. New Capitalism. Polity, 2009.

Goldar, Bishwanath. "Growth in Organised Manufacturing Employment in Recent Years." Economic and Political Weekly 46, no. 7 (February 12, 2011): 20-23.

Government of India, Ministry of Finance. Economic Survey 2015-16. New Delhi: Government of India, 2015. http://indiabudget.nic.in/survey.asp.

Government of India, Office of the Labour Commissioner. "The Factories Act, 1948, Chapter 1," March 23, 2014.

http://www.delhi.gov.in/wps/wcm/connect/DOIT_Labour/labour/home/acts+i mplemented/details+of+the+acts+implemented/the+factories+act $\% 2 \mathrm{C}+1948 / \mathrm{c}$ hapter+1.

Gupta, Dipankar. Nativism in a Metropolis: The Shiv Sena in Bombay. Delhi: Manohar Publishers, 1982.

Hansen, Thomas Blom. Wages of Violence: Naming and Identity in Postcolonial Bombay. New Jersey: Princeton University Press, 2001.

Harriss-White, Barbara. India Working. Cambrdige: Cambrdige University Press, 2003.

Hayter, Susan, ed. The Role of Collective Bargaining in the Global Economy: Negotiating for Social Justice, 2011.

Hensman, Rohini. Workers, Unions and Global Capitalism: Lessons from India. New Delhi: Tulika Books, 2011.

Hensman, Rohini, and Jairus Banaji. “A Short History of the Employees' Unions in Bombay, 1947-1991,” 2001.

International Commission for Labor Rights. "Merchants of Menace: Repressing Workers in India's New Industrial Belt,” June 2013.

http://www.laborcommission.org/files/uploads/2FINAL_Merchants_of_Mena ce_lo_res.pdf.

Kundu, Amitabh, and Lopamudra Ray Saraswati. "Migration and Exclusionary Urbanisation in India." Economic and Political Weekly 47, no. 26-27 (June 30, 2012): 219-27.

Mehrotra, Santosh, Ankita Gandhi, Bimal Kishore Sahoo, and Partha Saha. "Creating Employment in the Twelfth Five-Year Plan." Economic and Political Weekly, May 12, 2012.

Menon, Sreelatha. "Indian Trade Unions Are Getting Bigger, Coinciding with Slowdown." Business Standard India, April 6, 2013. http://www.businessstandard.com/article/economy-policy/indian-trade-unions-are-getting-biggercoinciding-with-slowdown-113040600392_1.html.

Mezzadri, Alessandra, and Ravi Srivastava. "Labour Regimes in the Indian Garment Sector: Capital-Labour Relations, Social Reproduction and Labour Standards in the National Capital Region." Monographs, October 2015. ttps://www.soas.ac.uk/cdpr/publications/reports/file106927.pdf. 
This is the Accepted Version of a forthcoming article that will be published by Taylor and Francis in Third World Quarterly: http://www.tandfonline.com/loi/ctwq20\#.V1a--vkrKM8

Accepted Version downloaded from SOAS Research Online: http://eprints.soas.ac.uk/22573/

Miyamura, Satoshi. "Diversity of Labour Market Institutions in Indian Industry: A Comparison of Mumbai and Kolkata." The Indian Journal of Labour Economics 54, no. 1 (January 2011): 113-30.

."Emerging Consensus on Labour Market Institutions and Implications for Developing Countries: From the Debates in India." Forum for Social Economics 41, no. 1 (April 1, 2012): 97-123. doi:10.1007/s12143-011-9099-4. . "Rethinking Labour Market Institutions in Indian Industry: Forms, Functions and Socio-Historical Contexts." Journal of Peasant Studies, forthcoming 2016.

Mohan, Archis, and Somesh Jha. "Sept 2 Strike: BMS Breaks Ranks with Other Unions.” Business Standard, August 29, 2015. http://www.businessstandard.com/article/current-affairs/in-a-first-bms-breaks-trade-union-ranks115082900615_1.html.

Monaco, Lorenza. "Bringing Operaismo to Gurgaon: A Study of Labour Composition and Resistance Practices in the Indian Auto Industry." $\mathrm{PhD}$ thesis in Development Studies, SOAS, University of London, 2015.

Munck, Ronaldo. Globalization and Labour: The New "Great Transformation." London and New York: Zed Books, 2002.

Nayyar, Deepak. Industrial Growth and Stagnation: The Debate in India. Bombay: Oxford University Press, 1994.

Pandey, Shruti J, and S. L. Shetty. "ASI Results for 2011-12.” Economic and Political Weekly 49, no. 21 (May 24, 2014): 89-93.

Pattenden, Jonathan. Labour, State and Society in Rural India. Manchester: Manchester University Press, 2016.

Ramaswamy, E. A. Worker Consciousness and Trade Union Response. Delhi: Oxford University Press, 1988.

Roy, Satyaki. "Unorganised Manufacturing, Flexible Labour and the 'Low Road': Lessons from Contemporary India." In Labor, Globalization and the State: Workers, Women and Migrants Confront Neoliberalism, edited by Debdas Banerjee and Michael Goldfield. New York: Routledge, 2007.

Sanyal, Kalyan, and Rajesh Bhattacharyya. "Beyond the Factory: Globalisation, Informalisation of Production and the New Locations of Labour." Economic and Political Weekly 44, no. 22 (May 30, 2009): 35-44.

Sen, Ratna. "Organizing the Unorganized Workers: The Indian Scene." Indian Journal of Industrial Relations 48, no. 3 (January 2013): 415-27. . "West Bengal." In Industrial Relations in Indian States, edited by C. S. Venkata Ratnam. Delhi: Global Business Press, 1996.

Sen, Sukomal. Working Class of India: History of Emergence and Movement, 18301990. Calcutta: K. K. Bagchi, 1997.

Shaikh, Anwar. Capitalism: Competition, Conflict, Crises. New York: Oxford University Press, 2016.

Sharma, Yogima Seth. "Government Ropes in India Inc to Frame Norms for Contract Labour." The Economic Times, September 2, 2013. http://economictimes.indiatimes.com//articleshow/22217403.cms.

Shyam Sundar, K. R. "Current State and Evolution of Industrial Relations in Maharashtra." Working paper, December 15, 2009. http://www.ilo.org/newdelhi/whatwedo/publications/WCMS_123330/lang-en/index.htm.

. "Industrial Conflict in India in the Post-Reform Period." Economic and Political Weekly 50, no. 3 (January 17, 2015): 43-53. 
This is the Accepted Version of a forthcoming article that will be published by Taylor and Francis in Third World Quarterly: http://www.tandfonline.com/loi/ctwq20\#.V1a--vkrKM8

Accepted Version downloaded from SOAS Research Online: http://eprints.soas.ac.uk/22573/

Silver, Beverly. "Theorising the Working Class in Twenty-First-Century Global Capitalism." In Workers and Labour in a Globalised Capitalism - Maurizio Atzeni, 46-69. London: Palgrave Macmillan, 2014.

Silver, Beverly J. Forces of Labor: Workers' Movements and Globalization Since 1870. Cambridge University Press, 2003.

Standing, Guy. Global Labour Flexibility: Seeking Distributive Justice. Palgrave Macmillan, 1999.

Teitelbaum, Emmanuel. Mobilizing Restraint: Democracy and Industrial Conflict in Post-Reform South Asia. Ithaca, NY: Cornell University Press, 2011.

Thompson, Edward Palmer. The Making of the English Working Class. IICA, 1963. tnlabour. "General Strikes : A Survey of Recent Strikes and What They Mean for the Working Class Movement," March 24, 2016. http://tnlabour.in/?p=3440.

van der Linden, Marcel. "The Crisis of World Labor." Against the Current 176 (June 2015). https://solidarity-us.org/node/4424.

Wood, Ellen Meiksins. Democracy Against Capitalism: Renewing Historical Materialism. Cambridge: Cambridge University Press, 1995.

Wright, Erik Olin. "Working-Class Power, Capitalist-Class Interests, and Class Compromise." American Journal of Sociology 105, no. 4 (January 2000): 957-1002.

\footnotetext{
1 'Class is defined by men [sic.] as they live their own history, and, in the end, this is its only definition’ (Thompson, The Making, 10); Wood, Democracy Against Capitalism; Bensaïd, Marx for Our Times.

${ }^{2}$ Banerjee, Globalisation, Industrial Restructuring; Roy, “Unorganised Manufacturing, Flexible Labour."

${ }^{3}$ Armstrong, Glyn, and Harrison, Capitalism Since 1945; Broad, "Globalization and the Casual Labor Problem"; Brenner, The Economics of Global Turbulence; Shaikh, Capitalism.

${ }^{4}$ Hensman, Workers, Unions; for debates on the slowdown in the 1960s, see Nayyar, Industrial Growth and Stagnation.

${ }^{5}$ Wright, "Working-Class Power, Capitalist-Class Interests"; Silver, Forces of Labor; Silver,

"Theorising the Working Class."

${ }^{6}$ Breman, The Labouring Poor in India; Harriss-White, India Working; Banerjee, Globalisation, Industrial Restructuring; Hensman, Workers, Unions; Das, "Reconceptualizing Capitalism"; Mezzadri and Srivastava, "Labour Regimes in the Indian Garment Sector"; Pattenden, Labour, State and Society in Rural India.

${ }^{7}$ Anant, "Labour Market Reforms in India"; Miyamura, "Emerging Consensus."

${ }^{8}$ Sen, Working Class of India; Bhattacherjee, "Organized Labour and Economic Liberalization"; Hensman, Workers, Unions.

${ }^{9}$ Mohan and Jha, "Sept 2 Strike."

${ }^{10}$ tnlabour, "General Strikes."

${ }^{11}$ Menon, "Indian Trade Unions Are Getting Bigger."

12 Shyam Sundar, "Industrial Conflict in India."

${ }^{13}$ Bhatt, We Are Poor but So Many; Bhowmik, "Cooperatives and the Emancipation of the Marginalized"; Chowdhury and Roma, "A Case Study of the NFFPFW"; Shyam Sundar, "Current State and Evolution of Industrial Relations in Maharashtra"; D'Cruz and Noronha, "Hope to Despair"; Sen, "Organizing the Unorganized Workers"; Shyam Sundar, "Industrial Conflict in India."

${ }^{14}$ International Commission for Labor Rights, "Merchants of Menace"; Monaco, "Bringing Operaismo to Gurgaon"; Shyam Sundar, "Industrial Conflict in India"; Aravamudan, "Can We Sit Down?"

${ }^{15}$ Standing, Global Labour Flexibility; Munck, Globalization and Labour; Doogan, New Capitalism; Sanyal and Bhattacharyya, "Beyond the Factory"; Davies and Vadlamannati, "A Race to the Bottom in Labor Standards?"; van der Linden, "The Crisis of World Labor." amongst many others.

${ }^{16}$ Wright, "Working-Class Power, Capitalist-Class Interests"; Silver, Forces of Labor; Silver,

"Theorising the Working Class."

${ }^{17}$ Anner, "Workers' Power in Global Value Chains."

${ }^{18}$ Anner, Solidarity Transformed; Anner, "Labor Control Regimes."
} 
This is the Accepted Version of a forthcoming article that will be published by Taylor and Francis in Third World Quarterly: http://www.tandfonline.com/loi/ctwq20\#.V1a--vkrKM8

Accepted Version downloaded from SOAS Research Online: http://eprints.soas.ac.uk/22573/

${ }^{19}$ The organised sector is defined as factory under the Factory Act of 1948. See Government of India, Office of the Labour Commissioner, "The Factories Act."

${ }^{20}$ Government of India, Ministry of Finance, Economic Survey 2015-16, 135-136.

${ }^{21}$ Sen, Working Class of India.

${ }^{22}$ Banerjee, Globalisation, Industrial Restructuring; Mehrotra et al., "Creating Employment," 66.

${ }^{23}$ Goldar, "Growth in Organised Manufacturing Employment"; Chandrasekhar and Sharma, "On the

Spatial Concentration"; Pandey and Shetty, "ASI Results for 2011-12."

${ }^{24}$ Kundu and Saraswati, "Migration and Exclusionary Urbanisation in India."

${ }^{25}$ For further details, see Miyamura, "Rethinking Labour Market Institutions."

${ }^{26}$ For a statistical analysis of institutional forms of labour organisations, see Miyamura, "Rethinking

Labour Market Institutions."

${ }^{27}$ Standing, Global Labour Flexibility.

${ }^{28}$ Roy, "Unorganised Manufacturing, Flexible Labour"; Hayter, The Role of Collective Bargaining, 309 .

${ }^{29}$ Davies and Vadlamannati, "A Race to the Bottom in Labor Standards?"

${ }^{30}$ Anner, Solidarity Transformed.

${ }^{31}$ Bhatt, We Are Poor but So Many.

${ }^{32}$ Silver, Forces of Labor; Silver, "Theorising the Working Class."

${ }^{33}$ Ramaswamy, Worker Consciousness and Trade Union Response; Sen, "West Bengal."

${ }^{34}$ Miyamura, "Rethinking Labour Market Institutions."

${ }^{35}$ Chibber, Locked in Place.

${ }^{36}$ While the BJP has involved Hindu nationalist ideology, Maharashtra's regional party Shiv Sena emerged as a Maratha-supremacist political movement. See Gupta, Nativism in a Metropolis; Hansen, Wages of Violence.

${ }^{37}$ Banaji and Hensman, Beyond Multinationalism: Management Policy and Bargaining Relationships in International Companies; Hensman and Banaji, “A Short History of the Employees' Unions”;

Hensman, Workers, Unions.

${ }^{38}$ Teitelbaum, Mobilizing Restraint.

${ }^{39}$ Shyam Sundar, "Industrial Conflict in India."

${ }^{40}$ Wright, "Working-Class Power, Capitalist-Class Interests"; Silver, Forces of Labor; Silver,

"Theorising the Working Class."

${ }^{41}$ Anner, Solidarity Transformed; Anner, "Labor Control Regimes."

${ }^{42}$ Anner, Solidarity Transformed.

${ }^{43}$ Although the case discussed in this article featured prominent roles played by company or plantbased unions independent of party-affiliation, the implication is not about preventing political parties to engage with the labour movement. Indeed, the fieldwork carried out for this research have shown that unions and union leaders affiliated to the same political party may play very different roles depending on the regional and organisational contexts. See Miyamura, "Rethinking Labour Market Institutions." ${ }^{44}$ Bhattacherjee, "The 'New Left."”

${ }^{45}$ Miyamura, "Diversity of Labour Market Institutions in Indian Industry."

${ }^{46}$ Bhattacharya, "Challenging 'Make in India."”

${ }^{47}$ International Commission for Labor Rights, "Merchants of Menace."

${ }^{48}$ Ibid.

${ }^{49}$ Silver, Forces of Labor; Anner, Solidarity Transformed.

${ }^{50}$ Shyam Sundar, "Industrial Conflict in India."

${ }^{51}$ International Commission for Labor Rights, "Merchants of Menace."

${ }^{52}$ See also Monaco, "Bringing Operaismo to Gurgaon."

${ }^{53}$ Breman, "The Study of Industrial Labour in Post-Colonial India"; Harriss-White, India Working;

Mezzadri and Srivastava, "Labour Regimes in the Indian Garment Sector"; Pattenden, Labour, State

and Society in Rural India. See also Mezzadri and Pattenden's contributions in this volume.

${ }^{54}$ Shyam Sundar, "Industrial Conflict in India."

${ }_{56}^{55}$ Menon, "Indian Trade Unions Are Getting Bigger."

${ }^{56}$ Thompson, The Making, 10; Wood, Democracy Against Capitalism.

${ }^{57}$ Sharma, "Government Ropes in India Inc to Frame Norms for Contract Labour."

${ }^{58}$ Bharatiya Janata Party (BJP), "Election Manifesto," 31.

${ }^{59}$ Confederation of Indian Industry (CII), "Engaging Contract Workforce."

${ }^{60}$ Selwyn, The Global Development Crisis. 